\title{
YALE
}

LAW JOURNAL

\begin{tabular}{lll}
\hline VOL. II & DECEMBER, 1892 & No. 2 \\
\hline
\end{tabular}

\section{THE MORAL RIGHT TO DEFEND THE GUILTY.}

By George D. Watrous.

This is by no means a new subject in itself. Indeed, few others in legal ethics have been more thoroughly discussed. But to every young man of conscience who takes up the study of the law, it is a new and often a serious one.

This fact, and my unwillingness to assent to many of the conclusions naturally to be drawn from the leading article of the last number of this Journal, must be my justification for adding to the abundant literature upon the question.

The moral tone of that article is admirable, and I should much regret to even seem to descend from its high level. But the author's suggestions cover much ground. Not only does he discuss the duties of a professional adviser upon a future course of conduct, but also those of one engaged to uphold his client's rights, where the past conduct of the client is the subject of judicial scrutiny. Where the advice of a lawyer is sought as a guide for future conduct; where he is to lead his client through intricate negotiations, the author's standard is not and cannot be too high. It is unquestionably his duty to avoid litigation and to aid or advise his client to do nothing which does not exactly square with justice. But a large part of his time and efforts must necessarily be devoted to ascertaining the legal consequences of past conduct. Can it be said that in such cases the proper standard of duty requires the 
lawyer to apply in the solution of such problems no other rule than that suggested by his own personal sense of abstract justice? Perhaps the author does not say or mean this. However, one might naturally draw conclusions which would result in what seems to me a misconception of the position which the lawyer is designed to occupy in the complicated system which the wisdom and experience of ages have devised for securing the greatest possible measure of justice and protection to mankind. Even conceding that in civil cases such a rule might apply, can it be said that in the course of the administration of criminal laws it is the lawyer's duty to seek to establish abstract justice ?

Indeed, can it be said that the term "justice" has any place, strictly speaking, in the administration of public law ? If it has, it would certainly seem to exhaust itself when the prisoner is given a fair trial according to the law of the land. To this end all criminal procedure is directed.

The criminal law is not concerned with rights between man and man; that is relegated to the civil law. The State prescribes such laws as it deems wise and expedient to protect the community against the consequences of acts, deemed inimical to the general welfare. If those consequences fall upon an individual, he has his remedy in the civil courts. There he may obtain compensation for the loss suffered- "justice" will be meted out between him and the wrong-doer. Not so in the criminal law. Society punishes acts deemed inconsistent with the public welfare. An offender is caught, convicted, and pardoned. To whom has any "injustice" been done by the pardon? Can any man, even the sufferer, claim that "justice" demands that the punishment be inflicted? Expediency may demand it, but is this "justice"? Justice is much higher. Justice involves the idea of applying the highest moral law to the facts of a case.

With the moral law the criminal law has no necessary connection. Most crimes are infractions as well of Divine and moral as of positive law. But it is the positive law which makes the acts criminal. If an act is in violation of Divine law, Divine disapproval is the penalty. In a certain sense it may be said that justice requires the punishment of the offender. But it is no part of human procedure to administer it. "Vengeance is mine, I will repay, saith the Lord."

If the transgression is of the moral law, popular disapproval is the penalty, but no human tribunal is empowered to infict it. The moral element is not of necessity present in a crime. The State of Connecticut deems it expedient to provide that any 
tradesman who shall, without consent of parent or guardian, give credit to a minor student, shall be guilty of a crime. This is no infraction of the moral, still less the Divine law.

The criminal law deals purely with matters of expediency. It is, of course, the privilege and the duty of good citizenship to have that law enforced. If it is not, can it be said that "injustice" has been done?

Certain principles form a part of that system of expediency. It must be admitted that life would be intolerable in any country where the accused is presumed guilty, and must assume the burden of proving his innocence. It must also be admitted that the laws ought to be clear and distinct and that no man ought to be punished unless clearly proven guility. It has also been deemed of vital concern to freedom that ex post facto laws should not be passed.

Justice toward the accused consists in securing him a fair trial according to existing law and existing rules of procedure. This procedure has been carefully devised as the best possible for the ascertainment of the truth. It is possible that it might be said that justice toward him would require an avoidance of any such disproportion between punishment and offense as would be abhorrent to the community. Yet even this use of the term is questionable.

But as to justice against the prisoner, there is certainly no such thing. If the guilty escape, to whom has injustice been done ?

It is to be hoped that the impression has not been left that the moral law is never to be considered in connection with the positive law of legislatures and tribunals-very far from it. Back of all human law stands the moral law. Toward this as toward a goal every statute, every rule of law or of procedure, every man's conduct, ought to reach. Our system of criminal procedure approaches it as nearly as finite wisdom has thus far found it possible, and is in touch with it at every possible point.

Starting with these premises, what is the duty of a lawyer, with reference to the administration of criminal law? Must he endeavor to persuade court and jury to conform to his ideas as to the expediency of punishing the offender, according to whether the act charged be or be not, in his opinion, a violation of the moral law? And especially, may the counsel for the accused, in good conscience defend the prisoner, if he has reason to believe him to have done the act charged in the indictment? 
No problem in professional ethics has more thoroughly distracted the conscientious student, and none is more responsible for the ignorant and contemptuous opinion which really prevails among many laymen, that no lawyer can be an honest man or that no honest man can become a lawyer.

The honor of our profession is often assailed ; rarely with reason -almost invariably without. Many a lawyer errs. Is the propensity of mankind to err confined within the limits of our profession? The right for which I am contending has often been abused. Does it follow that there is no such right? Juries-never, it is to be remembered, made up of lawyers-often bring in verdicts abhorrent to the commùnity and in violation of their oaths. Must our profession bear the odium of this ?

Our subject cannot be disposed of off-hand as an abstract question of ethics. Many reasons may be given, on à priori grounds. But our inquiry is of interest to us only in connection with the administration of English and American criminal law, and a satisfactory answer compels a resort to the history of that law, and to that of the development of civil liberty under Anglo-Saxon institutions.

We must learn how inch by inch freedom wrested from tyranny the stronghold behind which it is now intrenched, and we must note the part which the lawyer has taken in this struggle and that which he occupies in the resultant system of procedure.

Nearly every step toward freedom is characterized by an enlargement of the lawyer's powers in the protection of those accused of crime. All of these things must be carefully considered, in order to appreciate the function of the lawyer in the complicated machinery of criminal administration, by means of which peace, prosperity and liberty are guaranteed to the people.

A lawyer is but a $\operatorname{cog}$ in this machine. If he fails in his duty the machine fails in its work. It is no more his place-his duty or his privilege-to usurp all the functions of administration, than for the $\operatorname{cog}$ to insist upon moving the fly-wheel.

As has been intimated; the arguments in support of the moral right of a lawyer to defend one accused of crime are of two distinct sorts; one resting upon à priori reasons; the other upon the facts of history.

For the sake of a full discussion I will state the question in its. broadest form. May a lawyer honorably defend his client, if he have reason to know him to be guilty of the crime charged?

Many of the arguments of the first class partake strongly of sophistry. It would be unfortunate if we were obliged to rest our 
case solely upon them, though there is much of sound reason mixed with much that is specious.

In the first place it is said, how can a lawyer know that his client is guilty? Because he has confessed his guilt? The testimony of many distinguished advocates leads us strongly to the conclusion that it is rarely that a guilty man confesses even to his attorney. His secret is far too dangerous to intrust into any man's keeping. A shrewd criminal knows very well, too, that no advocate, however dishonest, can throw himself with such zeal and devotion into the conduct of a defense, when burdened with a knowledge of the unworthiness of his cause. Were it the advocate's duty to abandon such a cause, however, real confessions would be almost unknown. But even if a confession be made, is it necessarily trustworthy? If inspired by remorse, it may be. But many and many an instance is on record where innocent parties have confessed to a guilt, for ulterior purposes. An innocent man has confessed to a crime to attract attention to himself, that a friend or relative may escape under cover of the suspicion, trusting to more careful investigation to establish his innocence.

Even more common have been the instances where ignorant persons, terrorized by the apparent force of the evidence against them, have confessed to uncommitted crimes in the hope of clemency. Threats and promises have wrung forth many such. In the Middle Ages, the rack and the thumb-screw extorted many a confession as the price of relief from the exquisite agony of the moment. A man of diseased mind, influenced by the suspicions of others, often believes himself responsible for a crime, and confesses it. But though a client's words are not to be believed, say some, at least the lawyer who investigates the case and prepares it for trial, acquires such a knowledge of the facts that he cannot take refuge behind a fiction, or the untrustworthiness of confessions. So then, these people would say, when a man gets such an insight into a case as to disclose strong grounds for suspecting a client's guilt, it then becomes his moral and Christian duty to abandon the wretch to his fate-nay, even more, to use every effort to bring him to punishment. Probably these same people would say it was the duty of a physician to refuse medical aid to a suspected murderer, or of the jailer to refuse him food. He ought not to live. Justice demands he should die. Oh no, say they in reply, we would not say this of a person merely under suspicion. We are only talking of a person really guilty. Yes, but who is to say what man is really guilty? Is each man to decide this for himself, and the credulous butcher to stop furnishing meat to-day, while the more 
skeptical baker may wait until to-morrow. Any standard other than that which the law sets, is too absurd for consideration.

The lawyer's duty after investigating the evidence, will be discussed later. But at the very least, say others, when a lawyer is himself a witness of the crime, he can certainly not undertake the prisoner's defense. Let us see about this, for it needs an answer, though such cases are rare in practice. I see a man raise a gun to his shoulder and aim it at another; I hear a report and see that other fall. Upon these facts it cannot with any certainty be said that I have witnessed the crime of murder. Without going so far as to question whether something else may not have caused the fall, if we are convinced that the one did shoot the other, is it still certainly a crime? He may have shot in defense of his own life or limb-justifiable both in law and morals; he may have had no intention of pulling the trigger; he may have recklessly pulled it not knowing that the gun was loaded; or what is more serious, and more difficult of detection, he may not have had the capacity to form a criminal intent. Without this there can be no crime. We may witness the deed but not the intent. The suggestion of these possibilities may well make a lawyer hesitate before he ventures to usurp the functions committed to judge and jury, and, on his personal opinion, deny the prisoner the protection which the law extends to the meanest citizen. It is conceivable that a lawyer might be a sole witness of acts so flagrant, so overwhelming as evidence of guilt, that his duty as a citizen might stand first. The duty to give his testimony and give all possible assistance toward the enforcement of existing laws might outrank that of defending the prisoner, which would involve a suppression of that evidence. It would be far safer to decline such a case, on the ground of a conflict of duty. It would certainly be monstrous, if a criminal could escape punishment by retaining in his defense every lawyer who may have been a witness of his act. Such cases, however, must be rare.

Much of what precedes, I must confess, smacks unpleasantly of casuistry. Still, I trust that the soundness of the rest is equally apparent.

Now, let us look the question fairly in the face and assume that to a moral certainty the lawyer does know the client's guilt. Must he then decline the retainer, or if he has accepted it, withdraw from the case as soon as he learns the truth? If he must, the consequences to the accused are likely to be disastrous. He is from the first put on his guard against his own attorney, and all confidence between them is destroyed. If in spite of his caution, 
the attorney learns the truth, and it becomes his duty to withdraw, the prisoner is doomed. No other honorable lawyer could take the place of his counsel and every new refusal or withdrawal would add to the presumption of the prisoner's guilt when he comes before the jury. Conviction would almost certainly be the fate of a man prejudged - not by the constitutionally guaranteed tribunal - but by his own chosen counsel to whom he has turned for help and protection, but who turns against him to become judge, jury and accuser as well.

No such duty on the lawyer's part could possibly exist in a community where personal liberty is the dearest of all possessions, and where an impartial trial of every one accused is its surest guaranty. Only through the perverted notion that abstract justice demands an eye for an eye, and a tooth for a tooth, and constitutes every member of the community a tribunal with powers to accuse, to try, and to execute (though himself, so to speak, an interested party to the suit) could this claim be maintained.

The law has wisely provided otherwise, and we may now turn to the lessons taught by the constitutional history of England and of this country, in order to properly locate the lawyer's position in the administrative machinery of to-day.

It would be an interesting and a profitable study to trace out in detail the various steps in the evolution of modern civil liberty, and to note how closely connected they are with those in the development of criminal procedure. We can only call attention to some of the more prominent; enough to convince us of the trend of development.

In our every day life, freedom is so far the rule and restraint the exception, that we only with difficulty call to mind the centuries of struggles which have secured it to us. Magna Charta, The Petition of Right, The Habeas Corpus Act, The Bill of Rights, The Declaration of Independence and the United States Constitution are great landmarks along the road of progress toward civil freedom.

In the following outline sketch I have epitomized several portions of Stephen's "History of the Criminal Law of England" accepting the responsibility for all errors of statement.

The early history of the criminal law and procedure of England is wrapped in a haze, only translucent. It not only has been, but probably always will be, impossible to obtain any precise knowledge on these subjects.

We have much information of dubious authenticity, as to many curious institutions and customs. The later Anglo-Saxon and the 
earlier English laws enumerate several offenses, and lay down with much circumstantiality the penalties for them, but to the confusion of all principles of civil and criminal jurisprudence as now understood. The penalty is sometimes the "bot"-a compensation to an individual injured by the wrongful act of another; sometimes the "wite" - a fine paid to the king or other lord, by reason of the commission of an offense ; and sometimes the "wer" - a sum set upon a man's life to be paid to his relatives in case of his death by wrongful act. The idea of a public punishment for crimes had not been reached. The natural remedy for an act of violence was private vengeance, and the earliest traces of a criminal procedure seem to have been for the purpose of regulating the conditions of retaliation. This was one of the first forward steps.

The right of Infangthief, ${ }^{1}$ or summary execution, seems to have been a franchise granted to certain lords of townships. This appears to have survived the Conquest, and to have gradually given way under the restrictions put upon it. Side by side with it, and eventually displacing it, grew up a primitive police organization and a rude kind of courts, having both civil and criminal jurisdiction, and being in the nature of public meetings; the Hundred Courts, the County Courts, and the Courts of Franchises.

Since the Conquest there have been three modes of trial in criminal cases: by ordeal, by battle, and by jury. If compurgation be counted, there would be four, but as an institution this cannot be said to have survived the Conquest, though traces of it remained. There were also three modes of accusation: appeal, or accusation by a private person ; indictment, and information. ${ }^{2}$

The history of appeals and trial by battle go together, as the latter was an incident of the former. In civil cases it survived until its abolition in 1834 . Before the Conquest the individual accuser and the accused were both put under oath. The question of guilt or innocence was decided either by compurgation or ordeal, depending upon the character of the accused. ${ }^{3}$ If of good character he was entitled to the oath. If not, or if, as the expression was, the oath " burst," he had to go to the ordeal.

The compurgators swore not to particular facts, though probably they were permitted to examine witnesses before taking the oath, but as to their belief in the guilt or innocence of the accused.

1 I. Stephen Hist. of Crim. Law of Eng., p. 6r.

2 I. Stephen Hist. of Crim. Law of Eng., p. 244.

3 I. Stephen Hist. Crim. Law of Eng., p. 70. 
As to the ordeals, they were of many kinds, but of the same general nature. They were appeals to God to work some miracle to attest the prisoner's innocence. If the ordeal failed he was convicted. The relative value of the oaths of people of different ranks and professions was defined by law.

In the case of "appeals" since the Conquest, the procedure was, in brief, this : The appellor made a formal statement before the coroner, and steps were taken to secure the presence of the appellee. If he did not plead, or not adequately, battle was waged between the parties unless the guilt was too clear for doubt. If the appellee was defeated before the stars appeared, he was hanged.4 Otherwise he was acquitted of the appeal, but had to be tried by the country, as though indicted. Appeals in criminal cases were not abolished until the statute 59 Geo. III. c. 46. Ordeals appear to have lasted until the thirteenth century.

Before the Conquest, the ordinary criminal courts were subject to the supervision and concurrent jurisdiction of the King's Court or Curia Regis. Out of this developed the Courts of King's Bench, Oyer and Terminer, etc., as also the great civil courts. The jury system, in both civil and criminal cases, seems to have become an established institution by the middle of the fifteenth century. For a long period the jurors retained largely the functions of compurgators, and heard no witnesses. They were the witnesses, and only lately, comparatively speaking, did they become judges of fact.

These rude institutions are the sources from which our modern criminal trials have descended. How tenaciously even the crudest of them have clung to the system has been mentioned.

No time need be wasted in proving that in these earlier forms of procedure there was no place for counsel; equally useless would it be to do more than simply call attention to the fearful insecurity of human life and freedom. Where a man's only chance to prove his innocence of crime depends upon his ability to hold in his naked hand three pounds of red-hot iron, or to defeat his accuser in personal combat, it is idle to talk of any guarantees of freedom.

As our modern institutions gradually began to develop out of the older ones, in time it came to be recognized as fair that the accused might have a chance to say something as to the disposition that should be made of him.

4 I. Stephen Hist. of Crim. Law of Eng., p. 246. 
At first the jurors were not only witnesses, but might be examined and cross-examined by the justices. Later, witnesses were allowed in behalf of the prisoner, but they could not be sworn, and juries were cautioned against attaching too great weight to their testimony.

But even then, no counsel could appear in behalf of the accused, He was kept in close confinement and was not informed of the nature of the accusation, nor of the evidence against him. While he had the right upon the trial, without preparation, to fight for his life by personal altercation with the counsel for the Crown and their witnesses, what fairness was there in this, or how much of a chance for a man, to exercise his powers of examination or argument, even if he possessed them, with calmness and deliberation. The history of the State Trials shows that many of the best of lawyers lost their heads when confronted with such a task.

$U_{p}$ to 1688 , prisoners in cases of treason and felony had no counsel; throughout the eighteenth century none were allowed in cases of felony. A trial in those days was, to quote Stephen, "not unlike a race between the king and the prisoner, in which the king had a long start, and the prisoner was heavily weighted."

The influence of the Court of Star Chamber was very great in the improvement of this system.

What the Court of Chancery was in the development of a system of civil rights and remedies, this court was to criminal jurisprudence. Bacon describes it as "one of the sagest and noblest institutions of this kingdom."

The name of Star Chamber was given to the King's Council, when sitting as a court of criminal jurisdiction. Its principal function was to punish offenses not punishable by the Common Law. The procedure was closely analogous to that of chancery. The charge and the defendant's answer were like the bill and answer in chancery. Testimony was given by affidavit, and the parties appeared by counsel.

Both in substance and form, the action of the court was far in advance of that of the Common Law criminal courts. But the very uncertainty in the progressive growth of such an institution came to be regarded obnoxious. By reason of its tyrannical abuse of power in dealing with political offenses, the court fell into disfavor, and was abolished in 1640 .

Though nothing but the merest suggestion has been given of the defects in the earlier criminal procedure and of the several steps in the growth of our present system. this much seems clear: 
the whole tendency of the growth has been away from unfairness, and toward the ascertainment of the truth with absolute fairness toward the accused, under fixed and impartial rules, and in accordance with the teachings of centuries of bitter experience.

In this modern system we have a grand jury or an informing officer to make accusation, a judge, jury and opposing counsel. In general the accused may give evidence, and have process to compel the testimony of others. If he cannot pay for counsel, the State provides them. Every possible precaution is taken to secure fair play. The judge decides what grist shall go into the hopper ; the opposing counsel are the upper and nether millstones between which the evidence is ground into fragments; the jury separate the chaff from the wheat.

Let every officer of the court do his duty fully and conscientiously, and according to its present lights, human wisdom can accomplish nothing more. Every man has a right to a trial by due . process of law, and according to the law of the land. If after a fair trial in this manner a man cannot be convicted, it cannot be said that any moral right has been violated. A wise expediency does not and cannot demand more, and the criminal law has no other foundation.

Looking at the defendant's counsel as an officer of the court, having a definite part to play in the ascertainment of truth, it must be seen that any usurpation by him of the functions of judge or jury cannot but throw out of gear the whole administrative system.

If now it be admitted that a lawyer may honorably undertake the defense of one accused of crime, however much the public or the newspapers may clamor for vengeance, it is equally important to inquire how far he may go in the discharge of that duty. In all the bitter denunciations of Mr. Charles Phillips for his conduct of the famous Courvoisier case, his right to retain his client's brief was never seriously disputed; it was said that he abused it.

That case served as the text for many a heated discussion of a generation ago, and may serve as well as any other to-day, for an illustration of what by general consent a man may or may not do in defense of his client. Perhaps it has so far faded out of recollection as to warrant a brief statement of it here:

Courvoisier was indicted in 1840 for the murder of Lord William Russell, an old man of 73 , who lived in London in a house occupied only by himself and three servants; Courvoisier, a Swiss valet, the cook and housemaid. The evidence tended to show that the murder was committed by some one living in the house. 
The prisoner was defended by Mr. Phillips, an eminent barrister, and by a Mr. Clarkson. They went to trial fully persuaded of his innocence, and on the first day by a vigorous cross-examination of the other servants showed the purpose of intimating that they were at least as likely to be guilty. They also imputed to the police a disposition to fasten the proof upon the prisoner for the sake of reward.

After the close of the first day of the trial, it was discovered that a large quantity of the nobleman's plate had been left a few days before the murder with a Madame Piolane, who kept a place of resort in Leicester Place. The next morning she was shown a number of prisoners in the court yard, and instantly recognized Courvoisier as the man who had left it. He recognized her with dismay, and just before the opening of court called his counsel to the barand confessed the crime. He nevertheless insisted that they should defend him. Mr. Phillips at once refused to go on with the case, but at last yielded. He asked the advice of Baron Parke, who had been present at the trial, and was one of the most upright and conscientious men of his day. His advice was to go on. The same line of defense was continued and on the third day Mr. Phillips made a lengthy and powerful argument.

In spite of all, Courvoisier was convicted and afterward confessed. For the part he took Mr. Phillips was most strongly condemned by a leading newspaper; not for going on with the case, but because-it was said-by his acts and words he threw the whole weight of his personal character and affected belief into the scales; blasphemously called God to witness the innocence of his client; and cruelly tried to throw the blame upon the other servants and the police.

Unfortunately there is no authentic report of Mr. Phillips' speech, and most of the discussion turned into a dispute as to what he really said. Fortunate is it, on the other hand, for his reputation, that he had for a witness a man of such nicety of conscience as Baron Parke, who always stoutly justified his conduct. $\mathrm{He}$, it must be remembered, listened to the argument with a full appreciation of Mr. Phillips' distressing position. The evidence is almost conclusive that he did not do the things charged. But for purposes of criticism let us assume them to be true. What could a man in his position honorably do ? The answer must be sought in the obligations which the attorney assumes by his solemn oath of office, and in the principles of sound morality, with a full recognition of the important position in which the law places him. It is his duty to defend, but what are the limitations of this duty? 
Let us see what the oath of an attorney in this State requires, for this fairly represents the obligations generally assumed.

"You solemnly swear that you will do no falsehood, nor consent to any to be done in court, and if you know of any to be done, you will give information thereof to the judges, or one of them, that it may be reformed; you will not wittingly or willingly promote, sue or cause to be sued, any false or unlawful suit, or give aid or consent to the same; you will delay no man for lucre or malice; but will exercise the office of attorney, within the court wherein you may practice, according to the best of your learning and discretion, and with fidelity, as well to the court as to your client, so help you God."

Supplement this, if need be, by such principles of strict morality as should govern the conduct of any honorable man, and we find the standard of an attorney's duty. It cannot be difficult to apply this standard. The fabrication of evidence; the conscious introduction of false testimony; the spiriting away of witnesses; the making of false assertions to court or jury, are too gross forms of misconduct to need comment.

An assertion of belief in a client's innocence, if false, is beyond execration; if true, is unprofessional.

Sound morality will permit no man to expose himself to the temptation of yielding to the demand of the client that such assertions be made. Nor will it expose the client to the dangerous inference to be drawn from the failure to make them in particular cases. Equally unprofessional is it to impute guilt to the innocent to shield the guilty.

Every rational hypothesis which the facts in evidence may warrant, the attorney may draw, and insist with all his strength that if any exist consistent with that of the prisoner's guiit, he shall be acquitted. This is the prisoner's right. This much the law, embodying the results of the struggles of our ancestors for freedom, and the wisdom and experience of all ages, to which we are heirs, guarantees to every man accused of crime. It is no duty of the lawyer to withhold it. 